\title{
Determination of Polyphenol Components of Korean Prostrate Spurge (Euphorbia supina) by Using Liquid Chromatography - Tandem Mass Spectrometry: Overall Contribution to Antioxidant Activity
}

\author{
Yi Song, ${ }^{1}$ Sung Woo Jeong, ${ }^{1}$ Won Sup Lee, ${ }^{2}$ Semin Park, ${ }^{1}$ Yun-Hi Kim, ${ }^{1}$ \\ Gon-Sup Kim, ${ }^{3}$ Soo Jung Lee, ${ }^{4}$ Jong Sung Jin, ${ }^{5}$ Chi-Yeon Kim, ${ }^{6}$ Ji Eun Lee, ${ }^{1}$ \\ Se Yun Ok, ${ }^{1}$ Ki-Min Bark, ${ }^{7}$ and Sung Chul Shin ${ }^{1}$ \\ ${ }^{1}$ Department of Chemistry and Research Institute of Life Science, Gyeongsang National University, Jinju 660-701, Republic of Korea \\ ${ }^{2}$ Department of Internal Medicine, Institute of Health Sciences and Gyeongnam Regional Cancer Center, \\ Gyeongsang National University, Jinju 660-702, Republic of Korea \\ ${ }^{3}$ Research Institute of Life Science and College of Veterinary Medicine, Gyeongsang National University, Jinju \\ 660-701, Republic of Korea \\ ${ }^{4}$ Department of Food and Nutrition, Institute of Agriculture and Life Science, Gyeongsang National University, \\ Jinju 660-701, Republic of Korea \\ ${ }^{5}$ Division of High Technology Materials Research, Busan Center, Korea Basic Science Institute (KBSI), \\ Busan 618-230, Republic of Korea \\ ${ }^{6}$ Department of Dermatology Institute of Health Science, Gyeongsang National University Hospital, Jinju 660-702, Republic of Korea \\ ${ }^{7}$ Department of Chemical Education and Research Institute of Life Science, Gyeongsang National University, \\ Jinju 660-701, Republic of Korea
}

Correspondence should be addressed to Gon-Sup Kim; gonskim@gnu.ac.kr and Sung Chul Shin; sshin@gnu.ac.kr

Received 11 September 2013; Accepted 2 January 2014; Published 3 March 2014

Academic Editor: Shixin Deng

Copyright (c) 2014 Yi Song et al. This is an open access article distributed under the Creative Commons Attribution License, which permits unrestricted use, distribution, and reproduction in any medium, provided the original work is properly cited.

The Korean prostrate spurge Euphorbia supina is a weed that has been used in folk medicine in Korea against a variety of diseases. Nine polyphenols were characterized for this plant by using high-performance liquid chromatography-tandem mass spectrometry (HPLC-MS/MS) and the results were compared with the literature data. The individual components were validated using the calibration curves of structurally related external standards and quantified for the first time by using the validated method. Correlation coefficients $\left(r^{2}\right)$ were $>0.9907$. The limit of detection and limit of quantification of the method were $>0.028 \mathrm{mg} / \mathrm{L}$ and $0.094 \mathrm{mg} / \mathrm{L}$, respectively. Recoveries measured at $50 \mathrm{mg} / \mathrm{L}$ and $100 \mathrm{mg} / \mathrm{L}$ were $76.1-102.8 \%$ and $85.2-98.6 \%$, respectively. The total amount of the identified polyphenols was $3352.9 \pm 2.8 \mathrm{mg} / \mathrm{kg}$ fresh plant. Quercetin and kaempferol derivatives formed $84.8 \%$ of the total polyphenols. The antioxidant activities of the flavonoids were evaluated in terms of 1,1-diphenyl-2-picrylhydrazyl and $2,2^{\prime}$-azinobis(3-ethylbenzothiazoline-6-sulfonic acid) radical cation-scavenging activity, and the reducing power showed a dosedependent increase. Cell viability was effectively suppressed at polyphenol mixture concentrations $>250 \mathrm{mg} / \mathrm{L}$.

\section{Introduction}

The Korean prostrate spurge Euphorbia supina is a weed that belongs to the Euphorbiaceae family and is native to North
America. It is found in poor, drought-stressed turf and grows well during hot, dry weather in thin soils. It sprouts purplespotted, up to 0.60 -in oval leaves, and blooms very small, inconspicuous flowers in the summer [1]. 
The plant has been used in folk medicine in Korea against a variety of conditions such as diarrhea and suppurated swelling and as a styptic [2]. It was reported that the plant contains a number of biologically interesting organic substances, including terpenoids [3, 4], tannins, and polyphenols [5-7].

Of all bioactive natural constituents, polyphenols have attracted a great deal of interest, because they have beneficial effects to human health. Epidemiological studies have shown that polyphenols render many biological benefits, including a reduced risk of chronic diseases $[8,9]$ and antioxidant, antiaging, and antimicrobial properties [10]. In the plants, polyphenols function as physiologically active substances, such as attractants, feeding deterrents, materials used to communicate with the surrounding environment, and materials used as defense against biotic and abiotic stresses [11, 12]. Although the pharmaceutical efficacy of E. supina could be ascribed, at least partly, to the polyphenols, few studies have been conducted to validate this $[3,13]$.

The objective of the present study was to comprehensively characterize the polyphenol metabolomes of Korean $E$. supina by using high-performance liquid chromatographytandem mass spectrometry (HPLC-MS/MS) and to investigate their biological benefits, including antioxidant and hepatoprotective effects. HPLC-MS/MS is a useful technique for analyzing plant polyphenols, because it provides online structural information and characterizes unknown substances even when no reference standards are available [14].

\section{Materials and Methods}

2.1. Materials and Chemicals. E. supina was purchased in mid-April 2012 from a market in Jinju, South Korea. The plant was authenticated by Professor Moo Ryong Huh, a plant taxonomist with the Research Institute of Agricultural Life Science, Gyeongsang National University. A voucher plant was deposited in the herbarium at this institute. The plant was washed with water, lyophilized, and stored in dark containers at $-70^{\circ} \mathrm{C}$ until needed. All chemicals were purchased from Sigma-Aldrich Co., LLC (St. Louis, MO, USA). Gallic acid, protocatechuic acid, 7-hydroxycoumarin, quercetin 3$O$-glucoside, and kaempferol, which were purchased from Sigma-Aldrich Co., LLC (St. Louis, MO, USA), were used as external standards after recrystallization in ethanol. The purity of all standards was confirmed to be $>99 \%$ by using HPLC. All solvents and water were obtained from Duksan Pure Chemicals Co., Ltd. (Ansan, Republic of Korea).

2.2. Extraction and Purification. The lyophilized E. supina tissue $(10 \mathrm{~g})$ was ground into powder and extracted in ethyl acetate $(300 \mathrm{~mL})$ at $80^{\circ} \mathrm{C}$ for $20 \mathrm{~h}$. The extract was filtered through a Büchner funnel and concentrated at reduced pressure under $40^{\circ} \mathrm{C}$ by using a rotator evaporator. The concentrated solution was washed with $n$-hexane $(100 \mathrm{~mL}$ $\times 3)$, extracted with ethyl acetate $(100 \mathrm{~mL} \times 3)$, and dried over anhydrous sodium sulfate $\left(\mathrm{Na}_{2} \mathrm{SO}_{4}\right)$. The solvent was removed under reduced pressure. The sticky residue was placed on top of a silica gel sorbent $(3 \times 1.7 \mathrm{~cm}$ i.d. $)$ and eluted using a mixture of methanol:dichloromethane $(1: 5,25 \mathrm{~mL})$. The solvent was removed to give a mixture of polyphenols ( $0.9 \%$ of the dried plant). The mixtures were reconstituted in ethyl acetate $(0.03 \mathrm{~g} / \mathrm{mL})$, filtered through $0.45 \mu \mathrm{m}$ cellulose membranes, transferred into silanized vials, and stored at $-20^{\circ} \mathrm{C}$ until analysis.

2.3. HPLC-MS/MS. HPLC-MS/MS experiments were conducted according to a previously reported method [15], except for the use of a solvent system consisting of $0.5 \%$ aqueous formic acid (A) and methanol (B). The gradient conditions of the mobile phase were from 10 to $30 \%$ B over $10 \mathrm{~min}$, increased to $90 \% \mathrm{~B}$ over $40 \mathrm{~min}$, and increased again to $98 \%$ B over $5 \mathrm{~min}$.

2.4. Quantification and Validation. All components were quantified using chromatograms obtained at $254 \mathrm{~nm}$. The quantification was validated in terms of linearity, limit of detection (LOD), limit of quantification (LOQ), accuracy, and precision.

The individual components for which standards were not available, except for gallic acid (1) and protocatechuic acid (2), were quantified using the calibration curves of structurally related external standards. Thus, nodakenin (3) was quantified as 7 -hydroxycoumarin, quercetin derivatives $(4,5,8)$ as quercetin 3-O-glucoside, and kaempferol derivatives $(\mathbf{6}, 7$, 9) as kaempferol. Plant polyphenols can be quantified using a standard curve of structurally related compounds [16]. A stock solution of each standard $(10 \mathrm{mg} / \mathrm{L})$ was prepared by dissolving the appropriate amounts in methanol and storing at $-20^{\circ} \mathrm{C}$. Linearity was assessed using six different concentrations, $(1,10,50,100,1000$, and $2000 \mathrm{mg} / \mathrm{L})$ of each standard and by plotting the concentration of the standard against the peak area. LOD and LOQ were determined by injecting each standard solution into the HPLC until the signal-to-noise ratio for the standards reached $3: 1$ and $10: 1$, respectively. The accuracy of the methods was estimated as recovery $=\mathrm{A} / \mathrm{IS}-\mathrm{C} / \mathrm{B} / \mathrm{IS}-\mathrm{C}$, where $\mathrm{A}$ is the peak area obtained for the analyte spiked preextraction, $\mathrm{B}$ is the area obtained for the analyte spiked after extraction, and $C$ is the area of the blank extraction. The precision of the method was represented as a relative standard deviation (RSD).

2.5. Antioxidant Activity Measurement. A series of methanol solutions of the E. supina polyphenol mixture $(25,50,100$, 200 , and $500 \mathrm{mg} / \mathrm{L}$ ) were prepared and used for the antioxidant assay. Antioxidant activities were measured in terms of 1,1-diphenyl-2-picrylhydrazyl radical $\left(\mathrm{DPPH}^{\bullet}\right)$ and $2,2^{\prime}$ azinobis(3-ethylbenzothiazoline-6-sulfonic acid) $\left(\mathrm{ABTS}^{\bullet+}\right.$ ) radical cation-scavenging activity and reducing power (RP) assay according to a method reported in our previous studies [16].

\subsection{Effects of the Polyphenol Mixture of E. supina on Hep3B Cell Viability}

2.6.1. Cell Viability Assay. Hepatic cancer cells $\left(1 \times 10^{4}\right.$ cells per well) were plated onto 12 -well plates and treated 
TABle 1: Mass spectral data of the Euphorbia supina polyphenol mixture.

\begin{tabular}{lccc}
\hline Compounds & {$[\mathrm{M}-\mathrm{H}]^{-} /[\mathrm{M}+\mathrm{H}]^{+}$} & MS/MS & References \\
\hline Gallic acid (1) & 169 & $169,125,97$ & {$[17]$} \\
Protocatechuic acid (2) & 153 & $153,109,108$ & {$[17]$} \\
Nodakenin (3) & $/ 409$ & $409,391,353,389,247,229,203,185$ & {$[18]$} \\
Quercetin 3-O-hexoside (4) & 463 & $463,301,300,283,271,255,151$ & {$[16,19]$} \\
Quercetin 3-O-pentoside (5) & 433 & $433,300,273,271,255,179,151$ & {$[20]$} \\
Kaempferol 3-O-hexoside (6) & 447 & $447,285,255$ & {$[16,21]$} \\
Kaempferol 3-O-pentoside (7) & $/ 419$ & $419,309,287,155$ & {$[22,23]$} \\
Quercetin (8) & $/ 301$ & $301,273,179,153$ & {$[24,25]$} \\
Kaempferol (9) & $/ 287$ & $287,258,165,153,121$ & \\
\hline
\end{tabular}

TABLE 2: Regression data, limit of detection (LOD), and limit of quantification (LOQ) for the five external standards.

\begin{tabular}{|c|c|c|c|c|c|c|}
\hline \multirow{2}{*}{ Standard } & \multirow{2}{*}{ Calibration curve } & \multirow{2}{*}{$r^{2}$} & \multirow{2}{*}{$\begin{array}{c}\text { LOD } \\
(\mathrm{mg} / \mathrm{L})\end{array}$} & \multirow{2}{*}{$\begin{array}{c}\text { LOQ } \\
(\mathrm{mg} / \mathrm{L})\end{array}$} & \multicolumn{2}{|c|}{ Recovery (\%) \pm RSD } \\
\hline & & & & & $50 \mathrm{mg} / \mathrm{L}$ & $100 \mathrm{mg} / \mathrm{L}$ \\
\hline Gallic acid & $y=25.171 x+335.04$ & 0.9993 & 0.032 & 0.107 & $79.6 \pm 6.1$ & $85.2 \pm 0.5$ \\
\hline Protocatechuic acid & $y=37.614 x+1137.3$ & 0.9982 & 0.030 & 0.102 & $88.5 \pm 0.2$ & $87.8 \pm 0.5$ \\
\hline 7-Hydroxycoumarin & $y=10.873 x-28.39$ & 0.9955 & 0.142 & 0.473 & $102.8 \pm 0.7$ & $98.6 \pm 11.6$ \\
\hline Quercetin 3-O-glucoside & $y=30.166 x+267.56$ & 0.9949 & 0.037 & 0.125 & $76.1 \pm 0.1$ & $90.9 \pm 14.0$ \\
\hline Kaempferol & $y=39.493 x+1475.4$ & 0.9907 & 0.028 & 0.094 & $100.0 \pm 3.0$ & $97.4 \pm 1.4$ \\
\hline
\end{tabular}

$y$ : peak area of standard; $x$ : concentration of standard $(\mathrm{mg} / \mathrm{L})$.

with the polyphenol mixture of E. supina at concentrations of $31.25,62.5,125,250$, and $500 \mathrm{mg} / \mathrm{L}$ or vehicle (dimethyl sulfoxide, DMSO) alone for $24 \mathrm{~h}$. Cell viability was estimated by measuring the 3-(4,5-dimethylthiazol-2-yl)2,5-diphenyltetrazolium bromide (MTT) metabolism. Thus, $100 \mu \mathrm{L}$ of MTT solution ( $5 \mathrm{mg} / \mathrm{L})$ was added to each well of a 12-well plate, and the cells were maintained for $3 \mathrm{~h}$ at $37^{\circ} \mathrm{C}$. After the supernatant was removed, the remaining violet residue was dissolved in DMSO $(1 \mathrm{~mL})$. The absorbance values were measured using a microplate reader at $540 \mathrm{~nm}$. Cell viability was expressed as a percentage of proliferation versus controls, which was set at $100 \%$.

2.6.2. Cell Morphology Observation. Hep3B cells $\left(5 \times 10^{4}\right.$ cells per well) were plated onto 6-well plates and treated with the polyphenol mixture of E. supina at concentrations of $31.25,62.5,125,250$, and $500 \mathrm{mg} / \mathrm{L}$ or vehicle alone for $24 \mathrm{~h}$. Cell morphological change was observed under an optical microscope (Olympus CKX 41, Japan).

2.7. Statistical Analysis. All statistical analyses were performed according to a method described previously [16].

\section{Results and Discussion}

3.1. Separation and Characterization. A mixture of polyphenols was isolated from $E$. supina by methanol extraction at $80^{\circ} \mathrm{C}$, followed by elution in ethyl acetate over a silica gel cartridge. The polyphenols were characterized through HPLC by using a $\mathrm{C}_{18}$ column, MS/MS in negative- and positiveion modes, and comparison with the previous literature data. The HPLC chromatograms of the plant are shown in Figure 1.

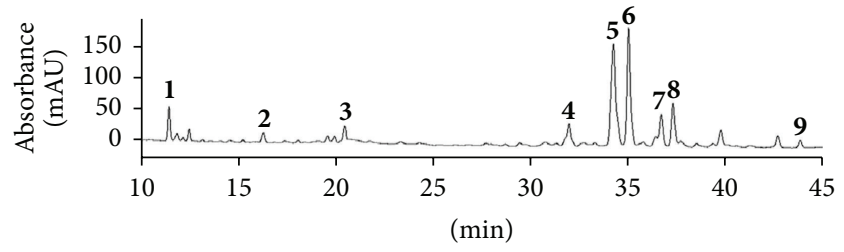

FIGURE 1: Chromatograms of the Euphorbia supina polyphenol mixture obtained using high-performance liquid chromatography:1, gallic acid; 2 , protocatechuic acid; $\mathbf{3}$, nodakenin; 4 , quercetin 3-Ohexoside; 5, quercetin 3-O-pentoside; 6, kaempferol 3-O-hexoside; 7, kaempferol 3-O-pentoside; 8, quercetin; 9, kaempferol. Detection wavelength: $254 \mathrm{~nm}$.

Nine polyphenols were labeled in the 10 to 45 min retention time segments of the chromatograms. The structures and HPLC-MS/MS data of the nine polyphenols are shown in Figure 2 and Table 1, respectively.

Polyphenol 1 was identified as gallic acid. Its MS/MS spectrum produced a $[\mathrm{M}-\mathrm{H}]^{-}$of $m / z 169$, which fragmented to yield $125\left[\mathrm{M}-\mathrm{H}-\mathrm{CO}_{2}\right]^{-}$and $97\left[\mathrm{M}-\mathrm{H}-\mathrm{CO}_{2}-\mathrm{CO}\right]^{-}$[17]. Polyphenol 2 was identified as protocatechuic acid. Its MS/MS consisted of $[\mathrm{M}-\mathrm{H}]^{-}$at $m / z 153$ and 109 [M-H$\left.\mathrm{CO}_{2}\right]^{-}$[17]. Component 3 was identified as nodakenin. Its MS/MS spectrum produced a $[\mathrm{M}+\mathrm{H}]^{+}$of $\mathrm{m} / z 409$, which fragmented to $247[\mathrm{M}+\mathrm{H}-\text { glucosyl }]^{+}, 229[\mathrm{M}+\mathrm{H}-$ glucosyl$\left.\mathrm{H}_{2} \mathrm{O}\right]^{+}$, and $203\left[\mathrm{M}+\mathrm{H}-\text { glucosyl- } \mathrm{CO}_{2}\right]^{+}[18]$. Polyphenol 4 yielded $[\mathrm{M}-\mathrm{H}]^{-}$of $\mathrm{m} / z$ 463, which fragmented to 301 $[\mathrm{M}-\mathrm{H}-\text { hexosyl }]^{-}, 283\left[\mathrm{M}-\mathrm{H}-\text { hexosyl- } \mathrm{H}_{2} \mathrm{O}\right]^{-}$, and $255[\mathrm{M}-$ $\mathrm{H}$-hexosyl- $\left.\mathrm{H}_{2} \mathrm{O}-\mathrm{CO}\right]^{-}$. Polyphenol 4 was quercetin 3-Ohexoside $[16,19]$. The MS/MS spectrum of polyphenol 5

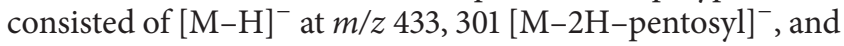


<smiles>[R]c1cc(C(=O)O)cc([R])c1[R]</smiles>

(1) $\mathrm{R}_{1}=\mathrm{OH}, \mathrm{R}_{2}=\mathrm{OH}, \mathrm{R}_{3}=\mathrm{OH}$

(2) $\mathrm{R}_{1}=\mathrm{OH}, \mathrm{R}_{2}=\mathrm{OH}, \mathrm{R}_{3}=\mathrm{H}$

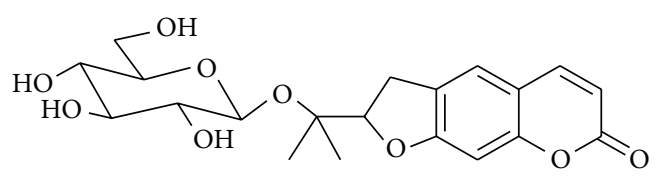<smiles>[R10]c1cc(-c2oc3cc(O)cc(O)c3c(=O)c2OC([R])O)ccc1O</smiles>

(4) $\mathrm{R}_{1}=\mathrm{OH}, \mathrm{R}_{2}=$ hexosyl

(5) $\mathrm{R}_{1}=\mathrm{OH}, \mathrm{R}_{2}=$ pentosyl

(6) $\mathrm{R}_{1}=\mathrm{H}, \mathrm{R}_{2}=$ hexosyl

(7) $\mathrm{R}_{1}=\mathrm{H}, \mathrm{R}_{2}=$ pentosyl

(8) $\mathrm{R}_{1}=\mathrm{R}_{2}=\mathrm{OH}$

(9) $\mathrm{R}_{1}=\mathrm{H}, \mathrm{R}_{2}=\mathrm{OH}$

3

FIGURE 2: Structures of the eight polyphenols and one nodakenin in Euphorbia supina.

TABLE 3: Concentration of polyphenols in Euphorbia supina $(\mathrm{mg} / \mathrm{kg}$ fresh plant).

\begin{tabular}{lc}
\hline Compounds & Mean \pm SD \\
\hline Gallic acid (1) & $264.4 \pm 0.7$ \\
Protocatechuic acid (2) & $124.3 \pm 0.3$ \\
Nodakenin (3) & $120.0 \pm 4.7$ \\
Quercetin 3-O-hexoside (4) & $458.3 \pm 4.9$ \\
Quercetin 3-O-pentoside (5) & $1648.2 \pm 20.2$ \\
Kaempferol 3-O-hexoside (6) & $553.8 \pm 4.2$ \\
Kaempferol 3-O-pentoside (7) & $126.9 \pm 1.5$ \\
Quercetin (8) & $118.7 \pm 1.0$ \\
Kaempferol (9) & $21.0 \pm 4.6$ \\
\hline Total & $3352.9 \pm 2.8$ \\
\hline
\end{tabular}

273 [M-2H-pentosyl-CO $]^{-}$; polyphenol 5 was identified as quercetin 3-O-pentoside [20]. Polyphenol 6 gave $[\mathrm{M}-\mathrm{H}]^{-}$at $\mathrm{m} / \mathrm{z} 447$, which produced $285\left([\mathrm{M}-\mathrm{H}]^{-}\right.$-hexosyl) and 255 $\left([\mathrm{M}-\mathrm{H}]^{-}-\right.$hexosyl- $\left.\mathrm{H}_{2}\right)$. It was identified as kaempferol 3-Ohexoside $[16,21]$. Polyphenol 7 was identified as kaempferol 3-O-pentoside. Its MS/MS consisted of $[\mathrm{M}+\mathrm{H}]^{+}$at $\mathrm{m} / z 419$ and $287[\mathrm{M}+\mathrm{H} \text {-pentosyl }]^{+}[22,23]$. Polyphenol 8 yielded $[\mathrm{M}+\mathrm{H}]^{+}$at $m / z 302$, which was fragmented to typical fragment ions $273[\mathrm{M}+\mathrm{H}-\mathrm{CO}]^{+}, 179\left[\mathrm{M}-\mathrm{CC}_{6} \mathrm{H}_{5} \mathrm{O}_{2}\right]^{+}$, and 153 $\left[\mathrm{C}_{7} \mathrm{H}_{5} \mathrm{O}_{4}\right.$, retro-Diels-Alder fragment]. Polyphenol 8 was quercetin $[24,25]$. Polyphenol 9 was identified as kaempferol and gave $[\mathrm{M}+\mathrm{H}]^{+}$at $\mathrm{m} / z 287$, which produced $257[\mathrm{M}+\mathrm{H}-$ $\mathrm{CO}]^{+}$and $153\left[\mathrm{C}_{7} \mathrm{H}_{5} \mathrm{O}_{4}\right.$, retro-Diels-Alder fragment $][26,27]$.

3.2. Quantification. The nine polyphenols identified in the Korean E. supina were quantified for the first time from peak areas of the LC-UV chromatogram obtained at $254 \mathrm{~nm}$. Quantification was validated based on representative external standards from the same group. The validation data are listed in Table 2. Regression equations were prepared in the form of $y=\mathrm{a} x+\mathrm{b}$, where $y$ and $x$ were the peak area and the concentration of each standard, respectively. The regression analysis showed correlation coefficients $\left(r^{2}\right)>0.9907$ for all five standards $(n=5)$, indicating good linearity. The LODs of the method were $0.028-0.142 \mathrm{mg} / \mathrm{L}$ and LOQs were $0.094-$ $0.473 \mathrm{mg} / \mathrm{L}$, indicating good performance limits. Recoveries measured at $50 \mathrm{mg} / \mathrm{L}$ and $100 \mathrm{mg} / \mathrm{L}$ were $76.1-102.8 \%$ and $85.2-98.6 \%$, respectively. Precisions of the method at $50 \mathrm{mg} / \mathrm{L}$ and $100 \mathrm{mg} / \mathrm{L}$ were $0.1-6.1 \%$ and $0.5-14.0 \%$, respectively. Both the accuracy and precision values were acceptable.

The contents of individual components are listed in Table 3. The total amount of the identified polyphenols was $3352.9 \pm 2.8 \mathrm{mg} / \mathrm{kg}$ fresh plant. Quercetin and kaempferol derivatives formed $84.8 \%$ of the total polyphenols. The plant comprised quercetin 3-O-pentoside (5) as the most dominant component, followed by kaempferol 3-O-hexoside (6). Quercetin, kaempferol, and their sugar-bound derivatives are major representatives of the polyphenol subclass that display the antioxidant activity to scavenge reactive oxygen species. As a result, E. supina, which is rich in such components, could be effective for reducing the risk of various chronic diseases resulting from oxidative damage, such as cancer, atherosclerosis, and inflammation $[27,28]$.

3.3. Antioxidant Activity. The polyphenol mixture isolated from Korean E. supina was evaluated for its antioxidant effects. Contemporary interest in polyphenols focuses on the epidemiological association between their potent antioxidant properties and a low incidence of chronic diseases. Epidemiological studies have shown that oxidative stress plays an important role in the pathogenesis of various chronic diseases, including cancer, cardiovascular disease, atherosclerosis, hypertension, diabetes, neurodegenerative disorders, rheumatoid arthritis, and aging [29-31]. Polyphenols can reduce oxidative stress and thus might protect and/or retard disease development [32, 33]; therefore, it is necessary to evaluate the antioxidant properties of the polyphenols in medicinal herbs. 
TABLE 4: Antioxidant activity (\%).

\begin{tabular}{|c|c|c|c|c|c|c|}
\hline & & & ncentration, $\mathrm{m}$ & & & Scavenoing activity \\
\hline & 25 & 50 & 100 & 200 & 500 & deavenging active \\
\hline DPPH & $29.85 \pm 0.86^{\mathrm{a}}$ & $31.75 \pm 1.41^{\mathrm{a}}$ & $40.88 \pm 1.15^{\mathrm{b}}$ & $47.63 \pm 1.93^{c}$ & $71.44 \pm 1.04^{\mathrm{d}}$ & $229.19 \pm 22.34^{\mathrm{A}}$ \\
\hline ABTS & $12.25 \pm 0.67^{\mathrm{a}}$ & $19.76 \pm 0.63^{\mathrm{b}}$ & $32.38 \pm 0.46^{\mathrm{c}}$ & $53.83 \pm 0.27^{\mathrm{d}}$ & $88.13 \pm 0.73^{\mathrm{e}}$ & $180.94 \pm 3.48^{\mathrm{A}}$ \\
\hline $\mathrm{RP}$ & $0.091 \pm 0.001^{\mathrm{a}}$ & $0.108 \pm 0.002^{b}$ & $0.132 \pm 0.002^{c}$ & $0.178 \pm 0.001^{\mathrm{d}}$ & $0.328 \pm 0.001^{\mathrm{e}}$ & $443.60 \pm 4.01^{B}$ \\
\hline
\end{tabular}

Assay wavelength: 1,1-diphenyl-2-picrylhydrazyl $(\mathrm{DPPH})=517 \mathrm{~nm}$ and 2,2'-azinobis(3-ethylbenzothiazoline-6-sulfonic acid) $($ ABTS $)=414 \mathrm{~nm}$, and reducing power $(\mathrm{RP})=700 \mathrm{~nm}$.

Butylated hydroxytoluene (BHT) EC 50 ; DPPH: $121.85 \pm 0.39 \mathrm{mg} / \mathrm{L}$; ABTS: $93.85 \pm 0.43 \mathrm{mg} / \mathrm{L} ; \mathrm{RP}: 26.71 \pm 0.69 \mathrm{mg} / \mathrm{L}$.

Each value represents mean \pm standard deviation $(\mathrm{SD}), n=5$.

${ }^{\mathrm{a}-\mathrm{e}}$ Means with different superscripts in the row are significantly different at $P<0.05$.

${ }^{\mathrm{A}} \mathrm{EC}_{50}(\mathrm{mg} / \mathrm{L})$ values were calculated from the calibration curves using five different concentrations $(25-500 \mathrm{mg} / \mathrm{L})$ in quintuplicate and their data were presented as $50 \%$ scavenging activity.

${ }^{\mathrm{B}} \mathrm{RP}$ value $\left(\mathrm{EC}_{0.3}\right)$ was reducing activity calculated from the calibration curves using five different concentrations $(25-500 \mathrm{mg} / \mathrm{L})$ in quintuplicate.

Antioxidant capacity can be evaluated by using a number of in vitro methods. Because the assay results are method dependent, a combined assay involving several methods is often used [34]. In this study, the antioxidant activity of the polyphenol mixture isolated from E. supina was determined by $\mathrm{DPPH}^{\circ}$ and $\mathrm{ABTS}^{\circ+}$ scavenging and RP assay at a concentration ranging from 25 to $500 \mathrm{mg} / \mathrm{L}$. In $\mathrm{DPPH}^{*}$ scavenging tests, antioxidant activity is monitored by measuring the disappearance of purple $\mathrm{DPPH}^{\circ}$, which can be detected spectrophotometrically at $517 \mathrm{~nm}$ [16]. In the $\mathrm{ABTS}^{*+}$ scavenging assay, the added antioxidants reduce the deep blue $\mathrm{ABTS}^{\circ+}$ to ABTS, and the decrease in absorbance of $\mathrm{ABTS}^{\circ+}$ at $414 \mathrm{~nm}$ is monitored [16]. The RP assay can also serve as an indicator of antioxidant activity. The added antioxidants convert the iron ion $\left(\mathrm{Fe}^{3+}\right)$ to $\mathrm{Fe}^{2+}$. The increase in absorbance of the deep-green $\mathrm{Fe}^{2+}$ solution at $\sim 700 \mathrm{~nm}$ is monitored [16]. The assay results are provided in Table 4 . The antioxidant capacity assayed using three methods showed a similar tendency. Thus, the antioxidant capacity of the E. supina polyphenol mixture showed a dose-dependent increase. $\mathrm{DPPH}^{*}$ or $\mathrm{ABTS}^{*+}$ scavenging activity can be represented as an $\mathrm{EC}_{50}$ value, which is the antioxidant concentration required to bring about a $50 \%$ loss in absorbance at $517 \mathrm{~nm}$ for $\mathrm{DPPH}^{\circ}$ and $414 \mathrm{~nm}$ for $\mathrm{ABTS}^{\circ+}$ as determined by linear regression analysis [16]. $\mathrm{RP}$ can be represented as $\mathrm{EC}_{0.3}$, which is the reducing activity presented by the sample concentration at 0.3 of the absorbance value at $700 \mathrm{~nm}$. Low $\mathrm{EC}_{50}$ and $\mathrm{RP}$ values signify high antioxidant activity [33]. The $\mathrm{DPPH}^{\circ}$ and $\mathrm{ABTS}^{\circ+}$ scavenging activity of butylated hydroxytoluene (BHT) as the control were $121.85 \pm 0.39 \mathrm{mg} / \mathrm{L}$ and $93.85 \pm 0.43 \mathrm{mg} / \mathrm{L}$, respectively. The $\mathrm{EC}_{0.3}$ value of $\mathrm{BHT}$ was $26.71 \pm 0.69 \mathrm{mg} / \mathrm{L}$. The antioxidant capacity values represented in terms of the $\mathrm{DPPH}^{\circ}$ and $\mathrm{ABTS}^{\circ+}$ scavenging activity and RP value were lower than those of BHT $(P<0.05)$.

\subsection{Growth Inhibitory and Morphological Effects of Polyphenol} Mixture of Korean E. supina. The anticancer activity of the polyphenol mixture of Korean E. supina was evaluated for human hepatocellular carcinoma Hep3B cells by MTT assay. The assay is a colorimetric method that measures cancer cell viability, quantifying the activity of the mitochondrial enzyme that reduces the yellow MTT molecule to purple

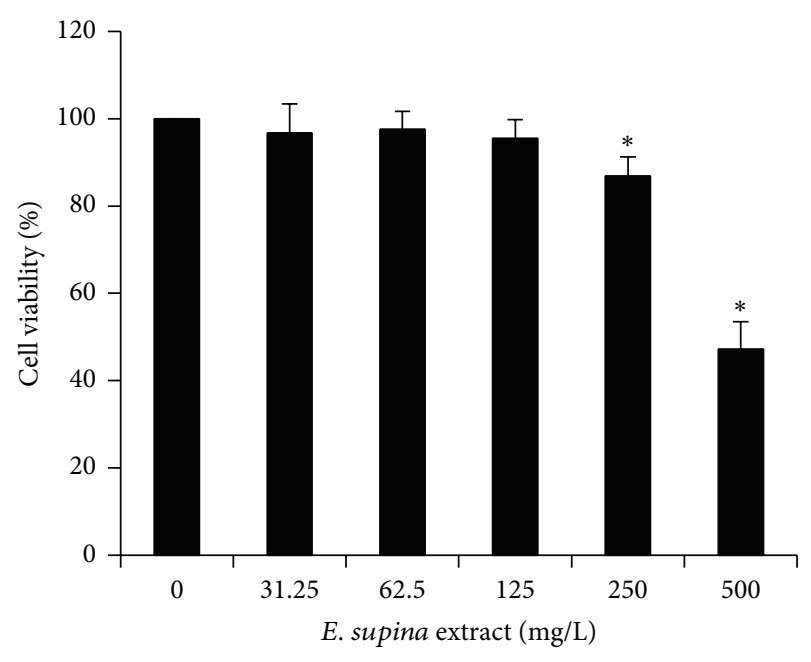

FIGURE 3: Antiproliferation effect on Hep3B cells by the Euphorbia supina polyphenol mixture. Hep3B cells were treated with the indicated concentrations of the E. supina polyphenol mixture for $24 \mathrm{~h}$ and viability was determined using 3-(4,5-dimethylthiazol-2-yl)2,5-diphenyltetrazolium bromide (MTT) assay. Data represent the mean \pm standard deviation (SD) of three replicates of independent experiments. The asterisk $(*)$ indicates a significant difference from the control group $(P<0.05)$.

formazan [34]. The cell line was incubated with serial concentrations of the polyphenol mixture ranging from 31.25 to $500 \mathrm{mg} / \mathrm{L}$ for $24 \mathrm{~h}$ and then subjected to MTT assays. The results are shown in Figure 3. The cell viability was decreased at polyphenol mixtures $>250 \mathrm{mg} / \mathrm{L}$, and the $\mathrm{IC}_{50}$ value was $500 \mathrm{mg} / \mathrm{L}$. After treatment with the polyphenol mixtures for $24 \mathrm{~h}$, the morphological changes such as loss of cell adhesion and floating cell debris were also observed, as shown in Figure 4. The MTT assay results and morphological changes show that the polyphenol mixtures effectively suppressed cell viability.

\section{Conclusion}

Nine polyphenols from the Korean E. supina were profiled using a single HPLC-MS/MS run. The antioxidant activities of the flavonoids were evaluated in terms of $\mathrm{DPPH}^{\circ}$ 


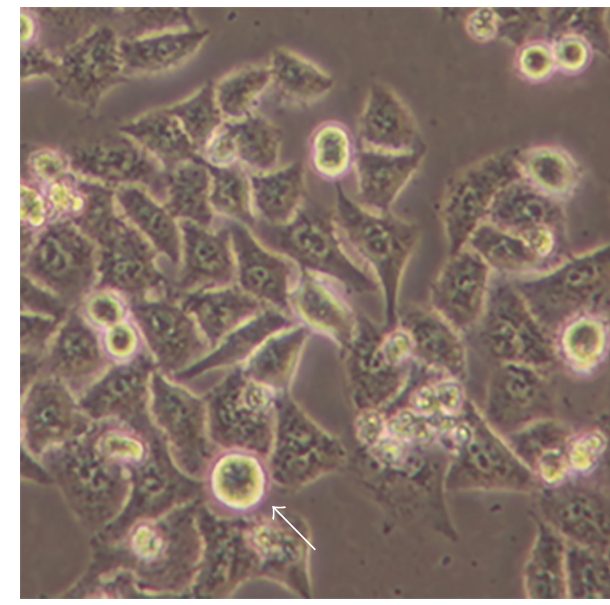

(a)

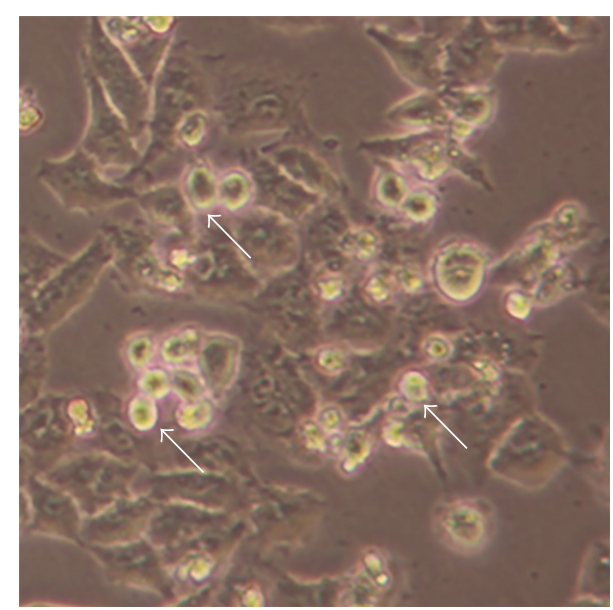

(c)

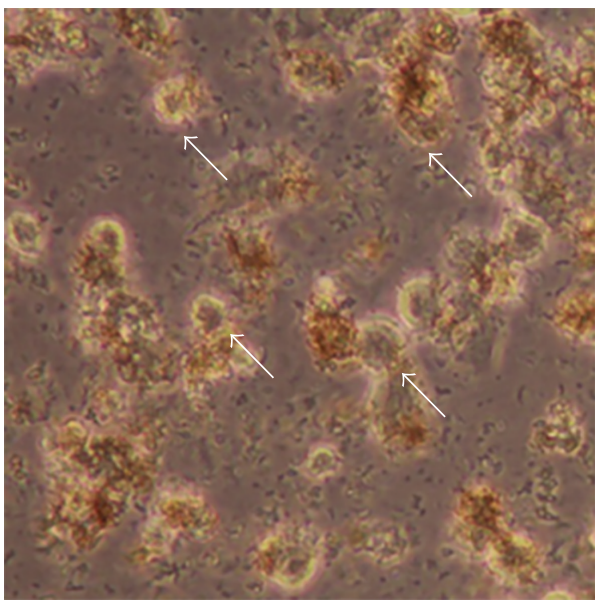

(e)

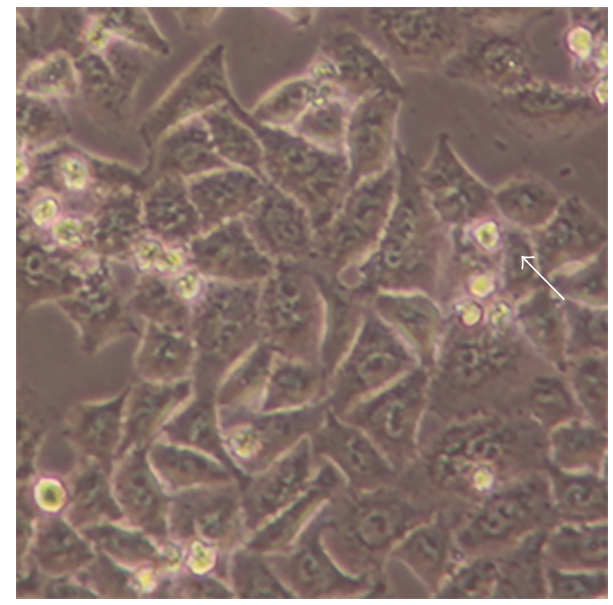

(b)

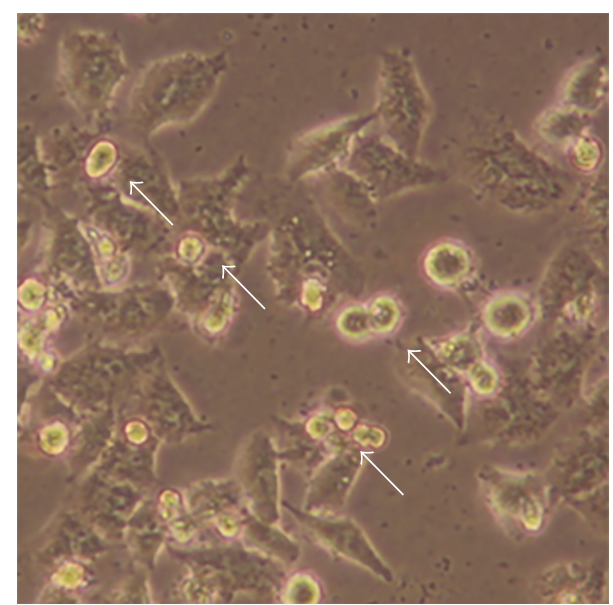

(d)

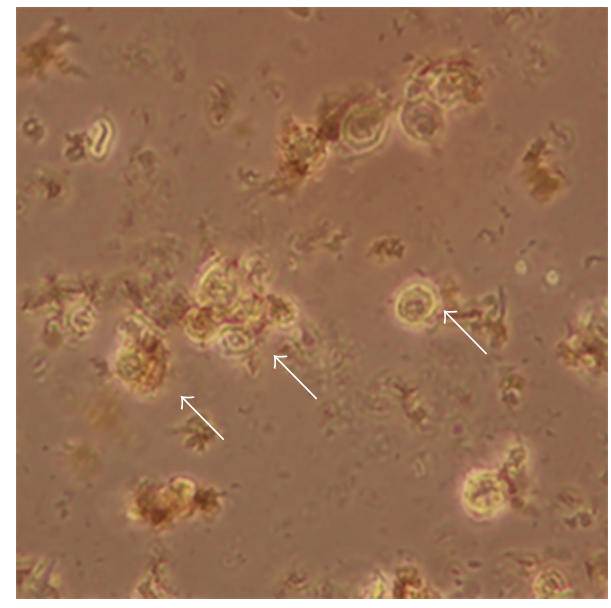

(f)

Figure 4: Morphological changes in Hep3B cells. Morphology of Hep3B cells visualized by optical microscopy $(\times 100)$. The cells were treated with various concentrations of the Euphorbia supina polyphenol mixture for $24 \mathrm{~h}$. (a) Control, (b) $31.25 \mathrm{mg} / \mathrm{L}$, (c) $62.5 \mathrm{mg} / \mathrm{L}$, (d) $125 \mathrm{mg} / \mathrm{L}$, (e) $250 \mathrm{mg} / \mathrm{L}$, and (f) $500 \mathrm{mg} / \mathrm{L}$. White arrows indicate suspended cells. 
and $\mathrm{ABTS}^{\bullet+}$ scavenging activities, and the reducing power showed a dose-dependent increase. Suppression of cell viability was observed at polyphenol mixture concentrations $>250 \mathrm{mg} / \mathrm{L}$.

\section{Conflict of Interests}

The authors declare that there is no conflict of interests regarding the publication of this paper.

\section{Authors' Contribution}

Yi Song, Sung Woo Jeong, and Won Sup Lee contributed equally to this study.

\section{Acknowledgments}

This study was supported by the National R\&D Program for Cancer Control, Ministry of Health \& Welfare, Republic of Korea (no. 0820050), and the National Research Foundation (NRF) of Korea Grant funded by the Korean government (MEST) (no. 2012R1A2A2A06045015).

\section{References}

[1] Prostrate Spurge Description, http://www.turf.uiuc.edu/weed _web/descriptions/prostratespurge.htm.

[2] R. Tanaka, M. Kurimoto, M. Yoneda, and S. Matsunaga, "17 $\beta, 21 \beta$-Epoxyhopan- $3 \beta$-ol and $\beta$-alnincanol from Euphorbia supina," Phytochemistry, vol. 29, no. 7, pp. 2253-2256, 1990.

[3] R.-B. An, J.-W. Kwon, T.-O. Kwon, W.-T. Chung, H.-S. Lee, and Y.-C. Kim, "Chemical constituents from the whole plants of Euphorbia supina Rafin," Korean Journal of Pharmacognosy, vol. 38, no. 3, pp. 291-295, 2007.

[4] R. Tanaka and S. Matsunaga, "Loliolide and olean-12-en$3 \beta, 9 \alpha, 11 \alpha$-triol from Euphorbia supina," Phytochemistry, vol. 28, no. 6, pp. 1699-1702, 1989.

[5] I. Agata, T. Hatano, Y. Nakaya et al., “Tannins and related polyphenols of euphorbiaceous plants. VIII. Eumaculin A and eusupinin A, and accompanying polyphenols from Euphorbia maculata L. and E. supina Rafin," Chemical and Pharmaceutical Bulletin, vol. 39, no. 4, pp. 881-883, 1991.

[6] S.-H. Lee, T. Tanaka, G. Nonaka, and I. Nishioka, "Tannins and related compounds. CV. Monomeric and dimeric hydrolyzable tannins having a dehydrohexahydroxydiphenoyl group, supinanin, euphorscopin, euphorhelin and jolkianin, from Euphorbia species," Chemical and Pharmaceutical Bulletin, vol. 39, no. 3, pp. 630-638, 1991.

[7] Z. Fang, X. Zeng, Y. Zhang, and G. Zhou, "Chemical constituents of spotted leaf euphorbia (Euphorbia supina)," Zhongcaoyao, vol. 24, pp. 230-233, 1993.

[8] I. Erlund, "Review of the flavonoids quercetin, hesperetin, and naringenin. Dietary sources, bioactivities, bioavailability, and epidemiology," Nutrition Research, vol. 24, no. 10, pp. 851-874, 2004.

[9] L. Le Marchand, "Cancer preventive effects of flavonoids-a review," Biomedicine and Pharmacotherapy, vol. 56, no. 6, pp. 296-301, 2002.

[10] Y. C. Xu, S. W. S. Leung, D. K. Y. Yeung et al., "Structure-activity relationships of flavonoids for vascular relaxation in porcine coronary artery," Phytochemistry, vol. 68, no. 8, pp. 1179-1188, 2007.

[11] D. Treutter, "Significance of flavonoids in plant resistance: a review," Environmental Chemistry Letters, vol. 4, no. 3, pp. 147$157,2006$.

[12] H. Nierheilig and Y. Piché, "Signalling in arbuscular mycorrhiza: facts and hypotheses," Flavonoids in Cell Function, vol. 505, pp. 23-39, 2002.

[13] H. K. Hong, J. H. Kwak, S. C. Kang et al., "Antioxidative constituents from the whole plants of Euphorbia supina," Korean Journal of Pharmacognosy, vol. 39, no. 3, pp. 260-264, 2008.

[14] E. de Rijke, P. Out, W. M. A. Niessen, F. Ariese, C. Gooijer, and U. A. T. Brinkman, "Analytical separation and detection methods for flavonoids," Journal of Chromatography A, vol. 1112, no. 1-2, pp. 31-63, 2006.

[15] H. G. Kim, G.-S. Kim, S. Park et al., "Flavonoid profiling in three citrus varieties native to the Republic of Korea using liquid chromatography coupled with tandem mass spectrometry: contribution to overall antioxidant activity," Biomedical Chromatography, vol. 26, no. 4, pp. 464-470, 2012.

[16] O. N. Seo, G.-S. Kim, S. Park et al., "Determination of polyphenol components of Lonicera japonica Thunb. Using liquid chromatography-tandem mass spectrometry: contribution to the overall antioxidant activity," Food Chemistry, vol. 134, no. 1, pp. 572-577, 2012.

[17] L. Chen, J. Qi, Y.-X. Chang, D. Zhu, and B. Yu, "Identification and determination of the major constituents in Traditional Chinese Medicinal formula Danggui-Shaoyao-San by HPLCDAD-ESI-MS/MS," Journal of Pharmaceutical and Biomedical Analysis, vol. 50, no. 2, pp. 127-137, 2009.

[18] X. Liu, S. Jiang, K. Xu et al., "Quantitative analysis of chemical constituents in different commercial parts of Notopterygium incisum by HPLC-DAD-MS," Journal of Ethnopharmacology, vol. 126, no. 3, pp. 474-479, 2009.

[19] S. Ek, H. Kartimo, S. Mattila, and A. Tolonen, "Characterization of phenolic compounds from lingonberry (Vaccinium vitisidaea)," Journal of Agricultural and Food Chemistry, vol. 54, no. 26, pp. 9834-9842, 2006.

[20] A. Lhuillier, N. Fabre, F. Moyano et al., "Comparison of flavonoid profiles of Agauria salicifolia (Ericaceae) by liquid chromatography-UV diode array detection-electrospray ionisation mass spectrometry," Journal of Chromatography A, vol. 1160, no. 1-2, pp. 13-20, 2007.

[21] N. Kumar, P. Bhandari, B. Singh, and S. S. Bari, "Antioxidant activity and ultra-performance LC-electrospray ionizationquadrupole time-of-flight mass spectrometry for phenolicsbased fingerprinting of Rose species: Rosa damascena, Rosa bourboniana and Rosa brunonii," Food and Chemical Toxicology, vol. 47, no. 2, pp. 361-367, 2009.

[22] M. Olszewska, "Quantitative HPLC analysis of flavonoids and chlorogenic acid in the leaves and inflorescences of Prunus serotina Ehrh," Acta Chromatographica, no. 19, pp. 253-269, 2007.

[23] H. K. Hong, J. H. Kwak, S. C. Kang et al., "Antioxidative constituents from the whole plants of Euphorbia supina," Korean Journal of Pharmacognosy, vol. 39, no. 3, pp. 260-264, 2008.

[24] Y.-J. Hong and A. E. Mitchell, "Metabolic profiling of flavonol metabolites in human urine by liquid chromatography and tandem mass spectrometry," Journal of Agricultural and Food Chemistry, vol. 52, no. 22, pp. 6794-6801, 2004.

[25] X. Meng, P. Maliakal, H. Lu, M.-J. Lee, and C. S. Yang, "Urinary and plasma levels of resveratrol and quercetin in humans, mice, 
and rats after ingestion of pure compounds and grape juice," Journal of Agricultural and Food Chemistry, vol. 52, no. 4, pp. 935-942, 2004.

[26] M. Dehkharghanian, H. Adenier, and M. A. Vijayalakshmi, "Study of flavonoids in aqueous spinach extract using positive electrospray ionisation tandem quadrupole mass spectrometry," Food Chemistry, vol. 121, no. 3, pp. 863-870, 2010.

[27] K. Murota and J. Terao, "Antioxidative flavonoid quercetin: implication of its intestinal absorption and metabolism," Archives of Biochemistry and Biophysics, vol. 417, no. 1, pp. 1217, 2003.

[28] J. M. Calderón-Montaño, E. Burgos-Morón, C. Pérez-Guerrero, and M. López-Lázaro, "A review on the dietary flavonoid kaempferol," Mini-Reviews in Medicinal Chemistry, vol. 11, no. 4, pp. 298-344, 2011.

[29] Oxidative stress, http://en.wikipedia.org/wiki/Oxidative_stress.

[30] E. Hopps, D. Noto, G. Caimi, and M. R. Averna, "A novel component of the metabolic syndrome: the oxidative stress," Nutrition, Metabolism and Cardiovascular Diseases, vol. 20, no. 1, pp. 72-77, 2010.

[31] T. Finkel, "Radical medicine: treating ageing to cure disease," Nature Reviews Molecular Cell Biology, vol. 6, no. 12, pp. 971976, 2005.

[32] M. Valko, D. Leibfritz, J. Moncol, M. T. D. Cronin, M. Mazur, and J. Telser, "Free radicals and antioxidants in normal physiological functions and human disease," International Journal of Biochemistry and Cell Biology, vol. 39, no. 1, pp. 44-84, 2007.

[33] J. H. Lee, S. J. Lee, S. Park et al., "Characterisation of flavonoids in Orostachys japonicus A. Berger using HPLC-MS/MS: contribution to the overall antioxidant effect," Food Chemistry, vol. 124, no. 4, pp. 1627-1633, 2011.

[34] T. Mosmann, "Rapid colorimetric assay for cellular growth and survival: application to proliferation and cytotoxicity assays," Journal of Immunological Methods, vol. 65, no. 1-2, pp. 55-63, 1983. 

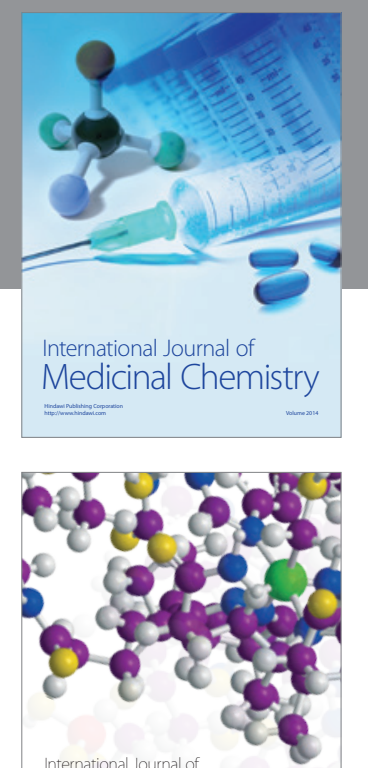

\section{Carbohydrate} Chemistry

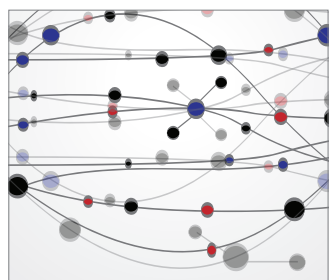

The Scientific World Journal
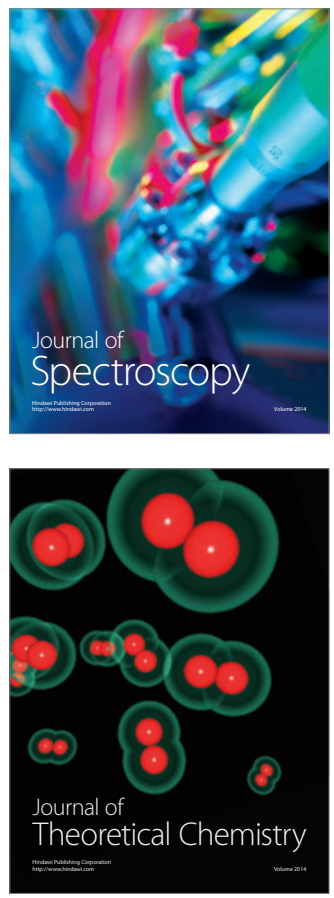
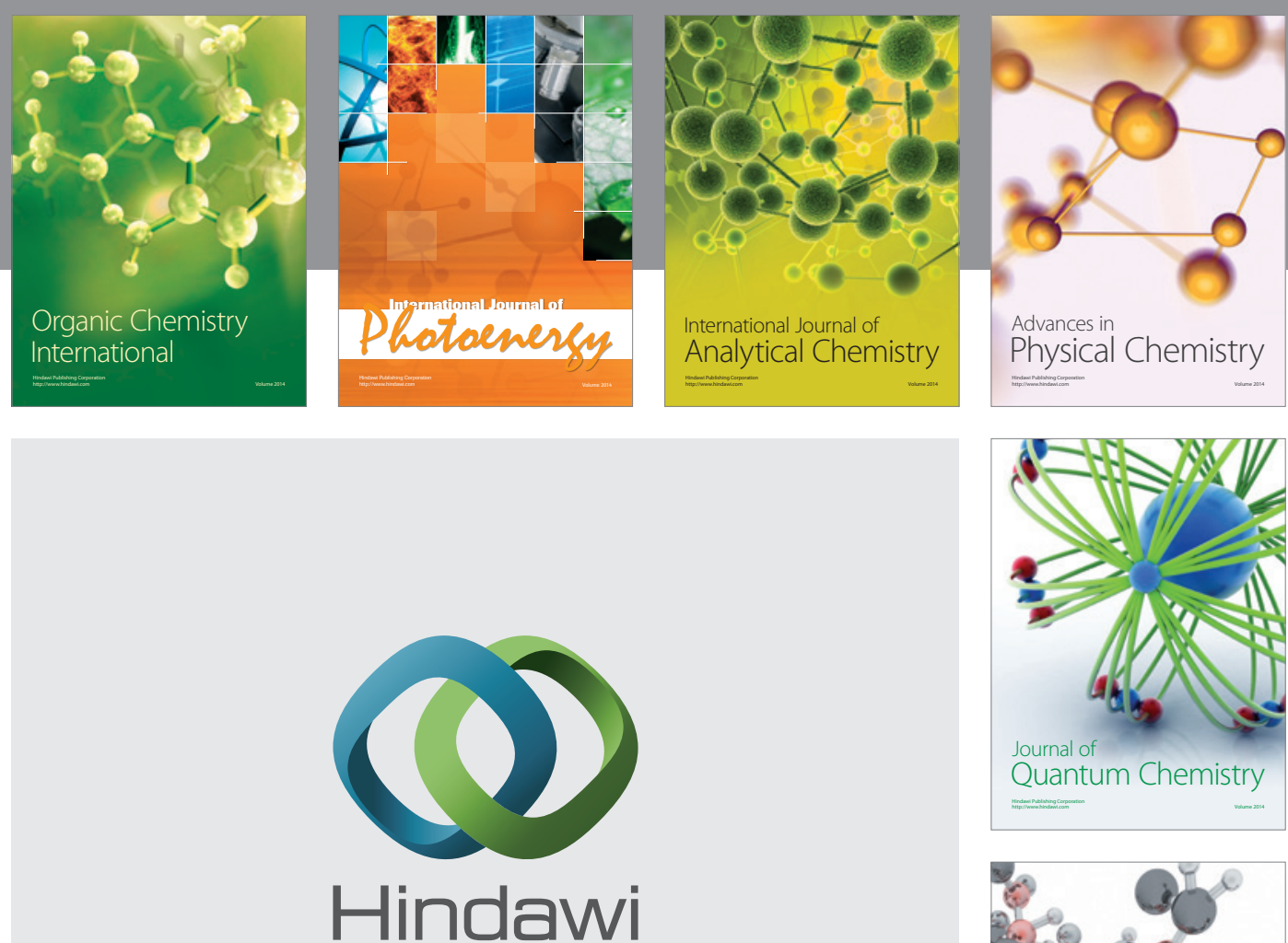

Submit your manuscripts at

http://www.hindawi.com

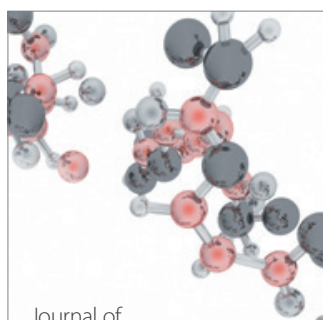

Analytical Methods

in Chemistry

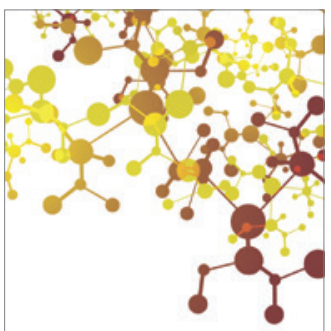

Journal of

Applied Chemistry

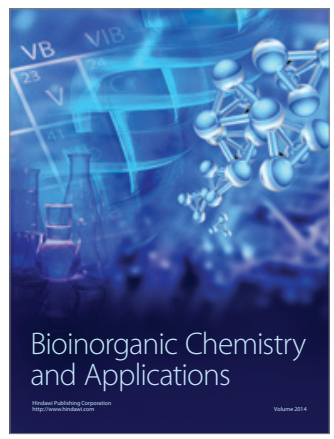

Inorganic Chemistry
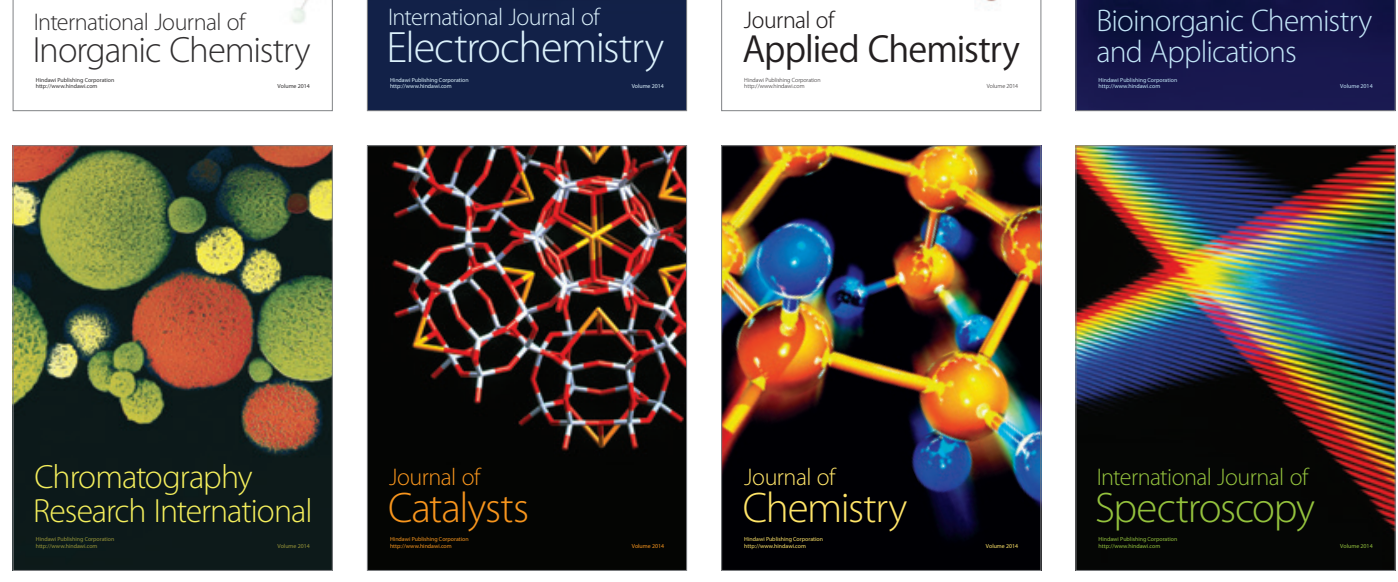